\begin{tabular}{|c|l|}
\hline Title & Risk assessment of ozone impact on Fagus crenata in Japan: consideration of atmospheric nitrogen deposition \\
\hline Author(s) & Watanabe, Makoto; Y amaguchi, Masahiro; Matsumura, Hidey uki; Kohno, Y oshihisa; Izuta, Takeshi \\
\hline Citation & $\begin{array}{l}\text { European Journal of Forest Research, 131(2), 475-484 } \\
\text { https://doi.org/10.1007/s10342-011-0521-5 }\end{array}$ \\
\hline Issue Date & 2012-03 \\
\hline Doc URL & http://hdl.handle.net/2115/52300 \\
\hline Type & article(author version) \\
\hline File Information & EJFOR2012_for_HUSCAP(Watanabe).pdf \\
\hline
\end{tabular}

Instructions for use 
Title

\section{Risk assessment of ozone impact on Fagus crenata in Japan: Consideration of atmospheric nitrogen deposition}

\section{Names of authors}

Makoto WATANABE ${ }^{1}$, Masahiro YAMAGUCHI ${ }^{2}$, Hideyuki MATSUMURA ${ }^{3}$, Yoshihisa $\mathrm{KOHNO}^{3}$ and Takeshi IZUTA ${ }^{4 *}$

\section{Affiliations and addresses}

${ }^{1}$ JSPS Research Fellow, Faculty of Agriculture, Hokkaido University, Sapporo 060-8589, Japan

${ }^{2}$ Faculty of Agriculture, Tokyo University of Agriculture and Technology, Fuchu, Tokyo 183-8509, Japan.

${ }^{3}$ Environmental Science Research Laboratory, Central Research Institute of Electric Power Industry, Abiko, Chiba 270-1194, Japan.

${ }^{4}$ Institute of Agriculture, Tokyo University of Agriculture and Technology, Fuchu, Tokyo 183-8509, Japan.

\section{Corresponding author}

Takeshi IZUTA

Tel. \& Fax.: +81-42-367-5728, E-mail: izuta@cc.tuat.ac.jp

Fuchu, Tokyo 183-8509, Japan. 
Abstract

Tropospheric ozone $\left(\mathrm{O}_{3}\right)$ is considered to be the air pollutiant relating to the decline of Fagus crenata forest in Japan. In the present study, we assessed a risk of $\mathrm{O}_{3}$ impact on the growth of $F$. crenata in Japan, giving consideration to the effects associated with atmospheric nitrogen $(\mathrm{N})$ deposition based on the experimental study, national monitoring data for oxidant concentration and atmospheric $\mathrm{N}$ deposition, and a national vegetation survey. The average and maximum $\mathrm{O}_{3}$-induced relative growth reduction $\left(R G_{\text {red }}\right)$ of $F$. crenata across Japan were estimated to be $3.2 \%$ and 9.7\%, respectively. Current levels of atmospheric $\mathrm{N}$ deposition were found to significantly affect the sensitivity of $F$. crenata to $\mathrm{O}_{3}$. When the $\mathrm{N}$ deposition was assumed as zero, the estimated average and maximum $R G_{\text {red }}$ were $2.3 \%$ and $5.7 \%$, respectively. The inclusion of atmospheric $\mathrm{N}$ deposition data thus increased the estimated values for average and maximum $R G_{\text {red }}$ (by $38 \%$ and $71 \%$, respectively). Our results demonstrate that a change in the sensitivity to $\mathrm{O}_{3}$ associated with atmospheric $\mathrm{N}$ deposition is an important consideration in the risk assessment of $\mathrm{O}_{3}$ impact on the growth of $F$. crenata in Japan.

\section{Keywords}

Ozone, Nitrogen deposition, Risk assessment, Fagus crenata, Growth reduction

\section{Introduction}

Tropospheric ozone $\left(\mathrm{O}_{3}\right)$ is recognized as a widespread phytotoxic gaseous air pollutant, and the concentration has been increasing in the Northern Hemisphere (Akimoto 2003; Matyssek and Sandermann 2003; ADORC 2006). In Japan, relatively high concentrations of $\mathrm{O}_{3}$ (above $100 \mathrm{nmol} \mathrm{mol}^{-1}$ ) have been frequently recorded not only in the suburbs of big cities such as Tokyo and Osaka, but also in 
several mountainous areas (Wakamatsu et al. 1998; Yoshikado 2004; Network Center for EANET 2007; Takeda and Aihara 2007). In Europe, the risk assessment of $\mathrm{O}_{3}$ impact on forest tree species has been conducted based on the concept of critical level, which was evaluated from experimental studies (Kärenlampi and Skärby 1996; Mills 2004; Simpson et al. 2007). On the other hand, although the current levels of $\mathrm{O}_{3}$ in Japan could adversely affect forest tree species, risk assessments of $\mathrm{O}_{3}$ impact were limited (Kohno et al. 2005; Watanabe et al. 2010).

The atmospheric deposition of nitrogen $(\mathrm{N})$ to terrestrial ecosystems has been increasing in line with elevated anthropogenic emissions of $\mathrm{N}$ (Ohara et al. 2007; Galloway et al. 2008). Several researchers reported relatively high amount of $\mathrm{N}$ deposition at 10 to $20 \mathrm{~kg} \mathrm{~N} \mathrm{ha}^{-1}$ year $^{-1}$ by wet $\mathrm{N}$ deposition (bulk precipitation) and 10 to $50 \mathrm{~kg} \mathrm{~N} \mathrm{ha}^{-1}$ year $^{-1}$ by throughfall and stemflow in the forested areas of Japan (Baba and Okazaki, 1998; Baba et al., 2001; Okochi and Igawa, 2001; Sase et al. 2008; Kimura et al. 2009).

In East Asia, emission of air pollutants such as $\mathrm{N}$ compounds and precursors of $\mathrm{O}_{3}$ has been increased rapidly since 1980 s owing to the increased energy demands due to rapid economic growth, industrialization and urbanization (Ohara et al. 2007; International Energy Agency 2008). Several researchers have implicated transboundary air pollution $\left(\mathrm{O}_{3}\right.$ and $\left.\mathrm{NO}_{\mathrm{X}}\right)$ from East Asian countries other than Japan as contributing to the recent increases in the concentration of $\mathrm{O}_{3}$ and atmospheric $\mathrm{N}$ deposition in Japan, especially in the areas along the Sea of Japan (Holloway et al. 2002; Ministry of the Environment 2004; Tanimoto et al. 2005; Yamaji et al. 2006; Han et al. 2007). In fact, the annual average daytime $\mathrm{O}_{3}$ concentration has been increased at a rate of $0.27 \mathrm{nmol} \mathrm{mol}^{-1}$ year $^{-1}$ between 1985 and 2007, whereas the emissions of precursors in Japan has been decreased during the same period (Ohara 
2011). The median value of the annual wet $\mathrm{N}$ deposition (sum of $\mathrm{NO}_{3}{ }^{-}$and $\mathrm{NH}_{4}{ }^{+}$) at 20 monitoring stations throughout Japan has been increased at a rate of $0.11 \mathrm{~kg} \mathrm{ha}^{-1}$ year $^{-1}$ between 1991 and 2007 (Ministry of the Environment 2009). Furthermore, continuous increase in the emission of air pollutants in the near future are predicted in East Asian countries (Ohara et al. 2007; International Energy Agency 2008). Therefore, tropospheric $\mathrm{O}_{3}$ concentration and atmospheric $\mathrm{N}$ deposition in Japan will increase through the transboundary air pollution if emissions of air pollutants will not be strictly controlled (Yamaji et al. 2008).

Since the increases in the $\mathrm{O}_{3}$ concentration and atmospheric $\mathrm{N}$ deposition are spatially correlated in general (Holland et al. 1997; Ollinger et al. 2002), we should consider interactive effects of atmospheric $\mathrm{N}$ deposition and $\mathrm{O}_{3}$ on forest tree species. There have been several experimental studies on the combined effects of $\mathrm{O}_{3}$ and the supply of $\mathrm{N}$ to the soil on the growth of various tree species. Utriainen and Holopainen (2001b) and Yamaguchi et al. (2007) reported that the supply of $\mathrm{N}$ to the soil increased the growth sensitivity of Pinus sylvestris and Fagus crenata seedlings to $\mathrm{O}_{3}$, respectively. However, opposite responses were reported for seedlings of Larix kaempferi and Populus tremula $\times$ Populus tremuloides (Watanabe et al. 2006; Häikiö et al. 2007). The effect of $\mathrm{N}$ supply on the sensitivity to $\mathrm{O}_{3}$ has not found to be significant for Picea abies seedlings (Utriainen and Holopainen 2001a; Thomas et al. 2005). These results indicate that atmospheric $\mathrm{N}$ deposition must be taken into account when we conduct a risk assessment of $\mathrm{O}_{3}$ impact on forest tree species whose sensitivity to $\mathrm{O}_{3}$ is affected by changes in the supply of $\mathrm{N}$ to the soil.

Fagus crenata is the most common and widely distributed deciduous broad-leaved tree species in the cool temperate forests of Japan (Nakashizuka and Iida 1995). F. crenata is an important tree species in Japan because its forests help to 
conserve forest soil and to maintain biodiversity, and is planted for afforestation as well as for ceremonial plantations (Murai et al. 1991; Nakashizuka 2004; Terazawa and Koyama 2008). Virgin natural forests of $F$. crenata on the Shirakami Mountains (northeast Japan) were registered by UNESCO as a World Natural Heritage sites in December 1993. Several researchers have implicated $\mathrm{O}_{3}$ as an important factor in the decline and dieback of $F$. crenata forests in Japan (Yonekura et al. 2001; Takeda and Aihara 2007; Kume et al. 2009). As discussed, the growth sensitivity of $F$. crenata seedling to $\mathrm{O}_{3}$ was found to be directly related to increases in the supply of $\mathrm{N}$ to the soil (Yamaguchi et al. 2007; Yamaguchi et al. 2010a). Therefore, the increase in the atmospheric $\mathrm{N}$ deposition in Japan may correspondingly increase the sensitivity of $F$. crenata to $\mathrm{O}_{3}$, thereby negatively affecting the growth of this tree species. However, a risk assessment of $\mathrm{O}_{3}$ impact on the growth of $F$. crenata in which atmospheric $\mathrm{N}$ deposition-induced changes in the sensitivity to $\mathrm{O}_{3}$ are considered has not been conducted. We addressed this in the present study, assessing the risk of $\mathrm{O}_{3}$ impact on the growth of $F$. crenata in Japan, giving consideration to the effects associated with atmospheric $\mathrm{N}$ deposition based on the experimental study, national monitoring data for oxidant concentration and atmospheric $\mathrm{N}$ deposition, and a national vegetation survey.

\section{Methods}

\subsection{The estimation of $\mathrm{O}_{3}$-induced growth reduction of Fagus crenata}

Our methods for estimating the effects of $\mathrm{O}_{3}$ on the growth of $F$. crenata were based on the results of Yamaguchi et al. (2007). In this study, the seedlings of $F$. crenata were grown under 12 experimental treatment conditions, as determined by the combination of 4 gas treatments (charcoal-filtered air and 3 levels of $\mathrm{O}_{3}$ at 1.0, 
1.5 and 2.0 times the ambient concentration) and 3 soil $\mathrm{N}$ treatments with $\mathrm{NH}_{4} \mathrm{NO}_{3}$ [0 (N0), 20 (N20) and $50 \mathrm{~kg} \mathrm{~N} \mathrm{ha}^{-1}$ year $^{-1}$ (N50)] in open-top chambers during the 2 growing seasons. The whole-plant dry mass increment for a single growing season $\left(W D M_{\text {inc }}\right)$ was calculated as the difference in the whole-plant dry mass of the seedlings between the ends of the first and second growing seasons. We measured the atmospheric concentration of $\mathrm{O}_{3}$ in the open-top chambers during the second growing season to calculate AOT40 (accumulated exposure over a threshold of 40 nmol mol ${ }^{-1}$, in $\mu \mathrm{mol} \mathrm{mol}{ }^{-1} \mathrm{~h}$ ) of $\mathrm{O}_{3}$ over $12 \mathrm{~h}$ periods (0600-1800 hours) between April and September. The AOT40 is the sum of the differences between the hourly mean $\mathrm{O}_{3}$ concentration and $40 \mathrm{nmol} \mathrm{mol}^{-1}$ for each hour when the $\mathrm{O}_{3}$ concentration exceeded $40 \mathrm{nmol} \mathrm{mol}^{-1}$ (Kärenlampi and Skärby 1996)

The analysis of the $\mathrm{O}_{3}$ exposure-response relationships for the $W D M_{\text {inc }}$ was performed according to Watanabe et al. (2007) as described below. A regression line was obtained from the relationship between AOT40 and the $W D M_{\text {inc. The theoretical }}$ $W D M_{\text {inc }}$ at zero AOT40 was determined to be the y-axis intercept of the regression line, and was used as a reference $(100 \%)$ to calculate the relative $W D M_{\text {inc }}$ for each gas treatment. The slope and coefficient of determination values $\left(R^{2}\right)$ were calculated from the regression line between AOT40 and the relative $W D M_{\text {inc. }}$ Because the sensitivity to $\mathrm{O}_{3}$ of $F$. crenata is reported to increase with an increase in $\mathrm{N}$ supply to the soil (Yamaguchi et al. 2007), this procedure was conducted separately for each $\mathrm{N}$ treatment. We regarded the absolute value of slope in the regression line as the $\mathrm{O}_{3}$-induecd relative growth reduction $\left(R G_{\text {red }}, \%\right)$ per unit AOT40 for each $\mathrm{N}$ treatment. The relationship between the amount of $\mathrm{N}$ supply and the $R G_{\text {red }}$ per unit AOT40 was analysed to estimate the $R G_{\text {red }}$ per unit AOT40 in the area with different depositions of $\mathrm{N}$. We calculated the $R G_{\text {red }}$ in each $F$. crenata habitat as a product of 
$R G_{\text {red }}$ per unit AOT40 and AOT40.

\subsection{Estimation of AOT40 of $\mathrm{O}_{3}$ in Japan}

The concentrations of photochemical oxidants are officially monitored at approximately 1200 monitoring stations throughout Japan. Originally, photochemical oxidants have been measured by absorption spectrophotometry using a neutral potassium iodide solution (AS-NPI). The atmospheric concentration of $\mathrm{O}_{3}$ can be tabulated as that of photochemical oxidants under the Air Pollution Control Law Enforcement Regulations in Japan from 1996, because of following reasons: a) the concentration of peroxi-acetyl nitrate (PAN), main component of photochemical oxidant without $\mathrm{O}_{3}$, was very low and b) the sensitivity of AS-NPI to PAN concentration was low (Ministry of the Environment 1996). In fact, the 1-year field measurement indicated that the little difference between the concentrations of $\mathrm{O}_{3}$ measured by UV absorption photometry and chemiluminescence method and that of photochemical oxidant measured by AS-NPI (Ministry of the Environment 1996). In the present study, therefore, the concentration of photochemical oxidants was regarded as that of $\mathrm{O}_{3}$.

The number of hours in which the concentration of $\mathrm{O}_{3}$ is above either 0.06 $\mu \mathrm{mol} \mathrm{mol}^{-1}\left(\mathrm{Num}_{60}\right)$ or $0.12 \mu \mathrm{mol} \mathrm{mol}^{-1}\left(\mathrm{Num}_{120}\right)$ is recorded by all of the monitoring stations in Japan and made available by the National Institute for Environmental Studies. However, hourly data concerning $\mathrm{O}_{3}$ concentrations were available in approximately $40 \%$ of prefectures. Ishii et al. (2007) reported a high correlation $(r=$ 0.97) between the sum of $N_{u m}$ and $N u m_{120}$ and the AOT40 over $12 \mathrm{~h}$ periods (0600-1800 hours) based on the monthly data between April and September, as calculated from available hourly $\mathrm{O}_{3}$ concentration data. Therefore, we use the 
method of Ishii et al. (2007) to estimate the AOT40 for all of the monitoring stations in Japan from 1999 to 2001.

The map of spatial distribution of AOT40 in Japan was created using the Geostatistical Analyst Extension of the ArcGIS 9.0 software (ESRI inc. USA). The kriging interpolation was applied for the estimation of AOT40 among the monitoring stations. The cell size in the kriging interpolation was set as $0.05^{\circ}$. The Gaussian model was used as a semivariogram model in the kriging interpolation because the kriging variance was lower than that of the other semivariogram models (Spherical, Circular, Exponential and Linear).

\subsection{Estimation of atmospheric $\mathrm{N}$ deposition in Japan}

In general, atmospheric $\mathrm{N}$ deposition is classified into wet deposition and dry deposition. We obtained wet deposition data for $\mathrm{NO}_{3}{ }^{-}$and $\mathrm{NH}_{4}{ }^{+}$from the Ministry of the Environment and Environmental Laboratories Association of Japan, which had monitoring station numbers of 97, 98 and 98 in 1999, 2000 and 2001, respectively (Environmental Laboratories Association 2003; Ministry of the Environment 2004). The distribution of wet deposition of $\mathrm{N}$ in Japan was estimated from these data. Flux of wet deposition of $\mathrm{N}\left(F_{\mathrm{w}}\right)$ was calculated from the concentration of $\mathrm{N}$ in precipitation $\left(C_{\mathrm{p}}\right)$ and the amount of precipitation $(P)$ as follows:

$$
F_{\mathrm{w}}=C_{\mathrm{p}} \cdot P
$$

Our method for estimating the dry deposition of $\mathrm{N}$ was based on that of Fujita (2004). The flux of dry deposition of $\mathrm{N}\left(F_{\mathrm{d}}\right)$ was calculated as the product of dry deposition velocity $\left(V_{\mathrm{d}}\right)$ and atmospheric $\mathrm{N}$ concentration $\left(C_{\mathrm{a}}\right)$ : 


$$
F_{\mathrm{d}}=V_{\mathrm{d}} \cdot C_{\mathrm{a}} .
$$

Puxbaum and Gregori (1998) reported the $V_{\mathrm{d}}$ of $\mathrm{N}$ compounds for several forests based on inferential models, and the average values across these forests were used in our calculations. The average $V_{\mathrm{d}}$ of gaseous $\mathrm{HNO}_{3}$, gaseous $\mathrm{NH}_{3}$, and particulate matter with $\mathrm{NO}_{3}{ }^{-}$and $\mathrm{NH}_{4}{ }^{+}$were $2.72,0.74$, and $0.18 \mathrm{~cm} \mathrm{~s}^{-1}$, respectively. $C_{\mathrm{p}}$ was considered as proportional to $C_{\mathrm{a}}$, and Formula 1 can be rewritten as follows:

$$
F_{\mathrm{w}}=K \cdot C_{\mathrm{a}} \cdot P
$$

where $K$ is the ratio of $C_{\mathrm{p}}$ to $C_{\mathrm{a}}$ (washout ratio). From Formulas 2 and $3, F_{\mathrm{d}}$ can be described follows:

$$
F_{\mathrm{d}}=V_{\mathrm{d}} \cdot F_{\mathrm{w}} /(K \cdot P)
$$

The dry deposition flux of $\mathrm{N}$ can thus be estimated by determining $K$. $C_{\mathrm{a}}$ values for gaseous $\mathrm{HNO}_{3}$ and $\mathrm{NH}_{3}$, and for $\mathrm{NO}_{3}{ }^{-}$and $\mathrm{NH}_{4}{ }^{+}$originating from particulate matter, were obtained alongside measurements of $C_{\mathrm{p}}$ values for $\mathrm{NO}_{3}{ }^{-}$and $\mathrm{NH}_{4}{ }^{+}$made by the 24-27 monitoring stations of the Environmental Laboratories Association of Japan between 1999 and 2001 (Environmental Laboratories Association 2003). K values were estimated from these data as the ratio of $C_{\mathrm{p}}$ to the sum of $C_{\mathrm{a}}$ values for gaseous and particulate forms. Extremely high $K$ values were observed at several monitoring stations. To avoid any spurious results potentially associated with their inclusion, we averaged $K$ values across the frequency distribution from the 10th to 90th percentile. This resulted in $K$ values that were averaged for each month (Fig. 1). For monitoring 
stations where $C_{\mathrm{a}}$ was not measured, its value was used. The commonly-used ratio of gaseous form $C_{\mathrm{a}}$ to particulate forms $C_{\mathrm{a}}$ (Gas/Particle) was estimated from data provided by the Environmental Laboratories Association (2003). Extremely high Gas/Particle values were observed at several monitoring stations, and, as for $K$ values, we used Gas/Particle values that were averaged across the frequency distribution from the 10th to 90 th percentile. The $F_{d}$ for all monitoring stations was estimated using Formula 2, and in to which $V_{\mathrm{d}}$ from Puxbaum and Gregori (1998) and measured or estimated $C_{\mathrm{a}}$ values were entered. To avoid change in $C_{\mathrm{a}}$ and $C_{\mathrm{p}}$ associated with the eruption of the Miyake volcano in August 2000, data from this month were omitted from the analyses.

The inverse distance weighted (IDW) method was applied for the estimation of values of wet and dry deposition of $\mathrm{N}$ among the monitoring stations. Cell size in the IDW interpolation was set as $0.2^{\circ}$. Total $\mathrm{N}$ deposition $\left(T N_{\text {dep }}\right)$ was calculated as sum of the wet and dry depositions of $\mathrm{N}$ in the GIS software.

\subsection{Habitats of Fagus crenata in Japan}

The habitats of $F$. crenata in Japan were determined from vegetation raster data $\left(45^{\prime \prime} \times 30 "\right.$ per mesh $)$ of the National Survey on the Natural Environment, conducted by the Ministry of the Environment. These data were obtained from the

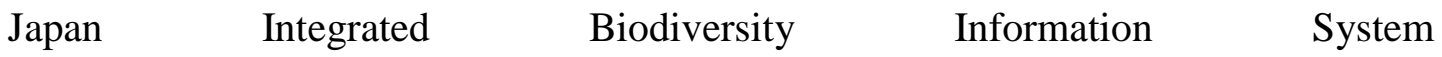
(http://www.biodic.go.jp/J-IBIS.html). Geographical meshes containing the vegetation code for $F$. crenata were taken to be $F$. crenata habitats. Figure 2 shows the habitats of $F$. crenata across various geographical regions of Japan. The AOT40 and $T N_{\text {dep }}$ for each $F$. crenata habitat were extracted from the above-mentioned AOT40 and $T N_{\text {dep }}$ map and were used to the calculation. 


\section{Results}

\subsection{Estimation of $R G_{\text {red }}$ per unit AOT40}

Figure $3 \mathrm{a}$ shows the relationship between AOT40 and the relative $W D M_{\text {inc }}$ of $F$ crenata seedlings. The slopes of the regression line were decreased with increasing the amount of $\mathrm{N}$ treatment. Although we found high values of the determination coefficient in the regression line for $\mathrm{N} 20$ and N50, that for $\mathrm{N} 0$ was low and not significant. The $R G_{\text {red }}$ per unit AOT40 increased linearly with increases in $\mathrm{N}$ supply (Fig. 3b). Therefore, we calculated the $R G_{\text {red }}$ per unit AOT40 with different $T N_{\text {dep }}$ by the formula of a regression line. With differing AOT40 $\left(\mu \mathrm{mol} \mathrm{mol}^{-1} \mathrm{~h}\right)$ and $T N_{\text {dep }}\left(\mathrm{kg} \mathrm{ha}^{-1} \mathrm{year}^{-1}\right)$, the $R G_{\text {red }}$ for each habitat of $F$. crenata was calculated as follows:

$$
R G_{\text {red }}=\left(0.0055 \cdot T N_{\text {dep }}+0.230\right) \cdot \mathrm{AOT} 40
$$

\subsection{Estimations of distribution in AOT40 and nitrogen deposition}

The highest AOT40 was estimated in the western part of the Kanto region (Fig. 4a). Relatively high AOT40 values were estimated not only for the areas along the Pacific Ocean where there are many big cities, and also for the areas along the Sea of Japan, including the northern parts of the Chubu and Chugoku regions. As shown in Fig $4 \mathrm{~b}$, relatively high $T N_{\text {dep }}$ was estimated in the western parts of the Kanto and Chubu regions. The average $T N_{\text {dep }}$ for Japan was $14.8 \mathrm{~kg} \mathrm{ha}^{-1} \mathrm{year}^{-1}$ and average ratio of dry deposition to wet deposition was 0.88 . 


\subsection{Estimated $\mathrm{O}_{3}$-induced relative growth reduction of Fagus crenata in Japan}

Relatively high $R G_{\text {red }}$ values for $F$. crenata were estimated across a relatively wide area comprising the northern part of the Chubu region and the northwestern part of Kanto region (Fig. 5a). The estimated $R G_{\text {red }}$ values for the western part of the Kanto region, the southern parts of the Chubu and Kinki regions, and the central part of the Chugoku region were also higher than for other areas. The average and maximum estimated $R G_{\text {red }}$ values for Japan were $3.2 \%$ and $9.7 \%$, respectively. As shown in Figure 6, the $R G_{\text {red }}$ for $F$. crenata increased with increasing AOT40. However, there was a large variation in the $R G_{\text {red }}$ across the range of AOT40 values, with the maximum value of the $R G_{\text {red }}$ per unit AOT40 20-30\% greater than the minimum. When the $T N_{\text {dep }}$ was assumed to be zero, the average and maximum estimated $R G_{\text {red }}$ values for Japan were $2.3 \%$ and $5.7 \%$, respectively (Fig. $5 \mathrm{~b}$ ). Thus, the average and maximum estimated $R G_{\text {red }}$ values were increased when atmospheric $\mathrm{N}$ deposition was considered (by $38 \%$ and $71 \%$, respectively).

\section{Discussion}

For $F$. crenata habitats, areas with relatively high AOT40 of $\mathrm{O}_{3}$ did not completely correspond to those with relatively high $T N_{\text {dep }}$ (Fig. 7): Relatively high AOT40 was estimated even where the $T N_{\text {dep }}$ was relatively low. This result differs from the previous reports by Holland et al. (1997) and Ollinger et al. (2002). The incomplete correspondence between $T N_{\text {dep }}$ and AOT40 was not explained by differences in the accumulation period. As mentioned above, transboundary air pollution from East Asian countries is considered to be a significant factor that affects $\mathrm{O}_{3}$ concentration and atmospheric $\mathrm{N}$ deposition in Japan (Holloway et al. 
2002; Ministry of the Environment 2004; Tanimoto et al. 2005; Yamaji et al. 2006; Han et al. 2007). The contribution of transboundary air pollution to the AOT40 of $\mathrm{O}_{3}$ in Japan is likely to be higher than that of $\mathrm{NO}_{\mathrm{X}}$ to $\mathrm{N}$ deposition, because the life time of $\mathrm{O}_{3}$ in the air is longer than that of $\mathrm{NO}_{\mathrm{X}}$. It is, therefore, possible that the incomplete correspondence between areas with relatively high $T N_{\text {dep }}$ and those with relatively high AOT40 is a result of increases in the AOT40 associated with transboundary air pollution.

Increase in the estimated $R G_{\text {red }}$ values associated with consideration of atmospheric $\mathrm{N}$ deposition was especially high (40-60\%) for the relatively wide area comprising the northern part of the Chubu region and the northwestern part of Kanto region. In Europe, a critical level of $\mathrm{O}_{3}$ for sensitive forest tree species, such as European beech and birch, was determined to be $5 \mu \mathrm{mol} \mathrm{mol}^{-1} \mathrm{~h}$ of daylight AOT40, value associated with a 5\% reduction in seedling growth (Karlsson et al. 2004; Mills 2004). The present study found the ratio of $F$. crenata habitats with $R G_{\text {red }}$ above $5 \%$ to all $F$. crenata habitats to be $0.3 \%$ when the $T N_{\text {dep }}$ was assumed to be zero. However, this ratio increased to $16.9 \%$ when atmospheric $\mathrm{N}$ deposition was considered. These results suggest that atmospheric $\mathrm{N}$ deposition-induced changes in the sensitivity to $\mathrm{O}_{3}$ must be taken into account in conducting a risk assessment of $\mathrm{O}_{3}$ for F. crenata in Japan.

The increase in $R G_{\text {red }}$ for $F$. crenata associated with an increase in the sensitivity to $\mathrm{O}_{3}$ induced by atmospheric $\mathrm{N}$ deposition may be important in terms of competition with other tree species. Kume et al. (2009) reported that $\mathrm{O}_{3}$ was an important contributor to the dieback of $F$. crenata in the mixed $F$. crenata and Cryptomeria japonica forest of the Toyama Prefecture in the northern part of the Chubu region (Fig. 2). Our risk assessment also indicates relatively high risk of $\mathrm{O}_{3}$ 
impact in this area. Relatively high concentrations of $\mathrm{O}_{3}$ were observed in this forest, while the concentrations of other air pollutant such as $\mathrm{NO}_{2}$ and $\mathrm{SO}_{2}$ were low (Kume et al. 2009). Although the total stem cross-sectional area at breast height of $C$. japonica increased, that of $F$. crenata decreased across 1999 to 2006 research period. As indicated by Kume et al. (2009), a difference in the sensitivity to $\mathrm{O}_{3}$ of $F$. crenata and $C$. japonica would explain this phenomenon. Indeed, numerous experimental studies have shown that while $F$. crenata is relatively sensitive to $\mathrm{O}_{3}, C$. japonica is tolerant (Izuta 2003; Kohno et al. 2005; Watanabe et al. 2006; Yamaguchi et al. 2007). On the other hand, the $T N_{\text {dep }}$ in this area estimated by the present study is about $19 \mathrm{~kg}$ $\mathrm{ha}^{-1}$ year $^{-1}$ (Fig. 4b). Because the supply of $\mathrm{N}$ to the soil stimulates growth of $C$. japonica and F. crenata to a similar extent (Watanabe et al. 2006; Yamaguchi et al. 2007), the effect of atmospheric $\mathrm{N}$ deposition on growth stimulation would not influence the competition between $F$. crenata and $C$. japonica. In contrast, the sensitivity of $C$. japonica to $\mathrm{O}_{3}$ does not change with changes in the amount of $\mathrm{N}$ supplied to the soil (Watanabe et al. 2006). The estimated $R G_{\text {red }}$ per unit AOT40 for $F$. crenata in this area was $45 \%$ higher than that with the $T N_{\text {dep }}$ assumed to be zero. It is, therefore, possible that by inducing a change in the sensitivity to $\mathrm{O}_{3}$, atmospheric $\mathrm{N}$ deposition in this region negatively affects the ability of $F$. crenata to compete with $C$. japonica.

The $\mathrm{O}_{3}$ concentration and atmospheric $\mathrm{N}$ deposition in Japan has been increasing through the transboundary air pollution and this trends will continue in the near future (Ohara et al. 2007; Yamaji et al. 2008; Ohara et al. 2011). In fact, the trends of increase in the $\mathrm{O}_{3}$ concentration and atmospheric $\mathrm{N}$ deposition in Japan have been observed after 1999-2001, which is the period that we assessed the risk of $\mathrm{O}_{3}$ impact in the present study (Ministry of the Environment 2009). Therefore, the 
risk of $\mathrm{O}_{3}$ impact on $F$. crenata in Japan at present time may be higher than that in the present study and will be serious by the increase in the $\mathrm{O}_{3}$ concentration and atmospheric $\mathrm{N}$ deposition in the near future.

In the present study, we combined data from an experiment study, field monitoring and vegetation survey, and produced a strong evidence that atmospheric $\mathrm{N}$ deposition should be included in the risk assessment of $\mathrm{O}_{3}$ impact on $F$. crenata. Because the present study is relatively extensive, we consider main uncertainties in the estimations of $\mathrm{O}_{3}$ sensitivity of $F$. crenata, AOT40 of $\mathrm{O}_{3}$ and atmospheric $\mathrm{N}$ deposition should be discussed. The relationship between AOT40 and $W D M_{\text {inc }}$ in the N0 treatment was not significant because of small extent of $\mathrm{O}_{3}$-induced reduction in $W D M_{\text {inc }}$, the limitation of the number of plot and relatively large variations (Fig. 3a). However, the value for the slope of the N0 treatment was reasonable to express the relationship between $T N_{\text {dep }}$ and $R G_{\text {red }}$ per unit AOT40 (Fig. 3b). Furthermore, when we used the data of each replication (i.e. $n=12$, Yamaguchi et al. (2007) applied 3 chamber replication), the relationship between $T N_{\text {dep }}$ and $R G_{\text {red }}$ per unit AOT40 in the N0 treatment was significant ( $\mathrm{p}=0.027$, data not shown). Yamaguchi et al. (2007) evaluated the effects of $\mathrm{N}$ supply to the soil on $F$. crenata seedlings. However, the actual $\mathrm{N}$ cycle in the forest ecosystem is more complex. For example, because plant can directly absorb the water from canopy leaves (Limm et al. 2009), the $\mathrm{N}$ deposition through fog and dew would be significant especially in the mountainous environment. There is a possibility that the effects of $\mathrm{N}$ uptake from leaves on $\mathrm{O}_{3}$ sensitivity is different as compared to the process from soil owing to a skip of soil chemical process. The growth sensitivity of $F$. crenata to $\mathrm{O}_{3}$ in the present study was evaluated by the experiment with seedlings in open-top chamber. There is a concern of differences in the sensitivities between seedlings and mature trees, and in the 
environmental conditions between open-top chamber and field (Karnosky et al. 2003; Matyssek et al. 2007). Therefore, we need further experimental studies to evaluate actual sensitivity of $F$. crenata in future for developing the risk assessment of $\mathrm{O}_{3}$ impact in Japan. Meanwhile, Pretzsch et al. (2009) reported a comparable growth sensitivity of mature Fagus sylvatica trees to $\mathrm{O}_{3}$ as compared to that of juvenile seedlings although the mechanism of $\mathrm{O}_{3}$-induced growth reduction may differ. Variations such as the area of individual leaf and physiological traits have been reported among F. crenata genotypes in Japan (Hagiwara 1977, Koike 1998). The provenance of $F$. crenata seedlings in the experiment of Yamaguchi et al. (2010a) is Nagano prefecture, belonging to the clade that distributes in the widest area (Chubu, western part of Tohoku and Hokkaido regions) in Japan (Fujii et al. 2002). These genetic variations of $F$. crenata may have an uncertainty for risk assessment because Paludan-Müller et al. (1999) reported that the sensitivities to $\mathrm{O}_{3}$ of $F$. sylvatica seedlings differed among the provenances in Europe. We did not have any information on the genetic variability in the sensitivities to $\mathrm{O}_{3}$ among $F$. crenata genotypes. In the near future, therefore, the comparison of $\mathrm{O}_{3}$ sensitivity among the $F$. crenata genotypes is needed to improve the quality of the risk assessment of $\mathrm{O}_{3}$ impact. Monitoring stations for $\mathrm{O}_{3}$ in Japan have been mainly located in the urban areas because the aim of monitoring is the protection of human health. There are limited number of monitoring station in the mountain and the rural areas. However, there are several phenomena that $\mathrm{O}_{3}$ concentration in mountain and rural areas were higher than that in urban region (Yamaguchi et al. 2010b). Furthermore, atmospheric concentration of $\mathrm{O}_{3}$ in mountainous areas sometimes show different diurnal variation as compared to urban areas (mainly flatland). Especially, little change in $\mathrm{O}_{3}$ the concentration under inversion layer is typical phenomenon in mountainous areas. 
This phenomenon make a concern when we estimate AOT40 based on the $\mathrm{Num}_{60}$ and $N_{u m} m_{120}$ according to Ishii et al. (2007). For example, two constant $\mathrm{O}_{3}$ concentrations at 70 and $100 \mathrm{nmol} \mathrm{mol}^{-1}$ show the same $N u m_{60}$ and $N u m_{120}$, but different AOT40. Reconsidering of the location of monitoring station for $\mathrm{O}_{3}$ and availability of hourly data are needed for accurate assessment of $\mathrm{O}_{3}$ impact on forest trees in Japan. At the present time, rutine method for measuring dry deposition of gases and particles has not yet established, while wet deposition continuously monitored throughout Japan. We needed the information on atmospheric dry deposition of $\mathrm{N}$ in large-scale because our aim is to clarify the extent of atmospheric $\mathrm{N}$ deposition-induced change in $\mathrm{O}_{3}$ risk for $F$. crenata throughout Japan. In the present study, therefore, we applied simple method for estimating atmospheric dry deposition of several $\mathrm{N}$ compounds with the data obtained from nationwide researches and constant value of $V_{\mathrm{d}}$ (Puxbaum and Gregori 1998; Environmental Laboratories Association 2003; Fujita 2004; Ministry of the Environment 2004). As a results, we clarified the importance of the change in the sensitivity to $\mathrm{O}_{3}$ associated with atmospheric $\mathrm{N}$ depsotion. In addition, similar amount of total dry $\mathrm{N}$ deposition as compared to that of total wet $\mathrm{N}$ deposition in the present estimation partly supports the validity of our estimation (Matsuda et al. 2001). The applied $V_{\mathrm{d}}$ values for gaseous $\mathrm{HNO}_{3}$ and particulate matter with $\mathrm{NO}_{3}{ }^{-}$and $\mathrm{NH}_{4}{ }^{+}$(2.72 and $0.18 \mathrm{~cm} \mathrm{~s}^{-1}$, respectively) are relatively lower than those in other studies, whereas the $V_{\mathrm{d}}$ for gaseous $\mathrm{NH}_{3}\left(0.74 \mathrm{~cm} \mathrm{~s}^{-1}\right)$ is similar (Hanson and Lindberg 1991; Endo et al. 2011). Therefore, there is a possibility that actual dry deposition of $\mathrm{N}$ is higher than our estimation. Although the estimation of parameters for dry deposition of $\mathrm{N}$ in Japan is difficult owing to the complex geography with monsoonal climate, the development of ideal method for estimating dry deposition of $\mathrm{N}$ that apply to nation wide scale is needed. 


\section{Conclusion}

The results of the present study lead us to conclude that the current level of atmospheric $\mathrm{N}$ deposition-induced change in the sensitivity to $\mathrm{O}_{3}$ is an important factor in the risk assessment of $\mathrm{O}_{3}$ impact on $F$. crenata in Japan. The average and maximum estimated $R G_{\text {red }}$ values increased when atmospheric $\mathrm{N}$ deposition was considered (by $38 \%$ and $71 \%$, respectively). Increases in the estimated $R G_{\text {red }}$ values were especially high, ranging from $40 \%$ to $60 \%$, in the wide areas comprising the northern part of the Chubu region and the northwestern part of Kanto region.

As reported previously, there are several tree species for which changes in the supply of $\mathrm{N}$ to the soil alters their sensitivity to $\mathrm{O}_{3}$ (Utriainen and Holopainen 2001b; Watanabe et al. 2006; Häikiö et al. 2007). For protecting these tree species, future risk assessments of $\mathrm{O}_{3}$ impact must be conducted with consideration of atmospheric $\mathrm{N}$ deposition.

\section{Acknowledgments}

This study was partly supported by the Ministry of the Environment, Japan through the program of Global Environmental Research Fund and by Japan Society for the Promotion of Science Research Fellowships for Young Scientists. The authors are greatly indebted to M. Iwasaki, J. Naba, N. Matsuo, C. Tabe, R. Yamashita, Y. Shinozaki and M. Tanaka (Tokyo University of Agriculture and Technology), and staff of CERES Inc. for their technical support and discussion. We use the data file of photochemical oxidant from "Numerical database for environment" of National Institute for Environmental Studies. 


\section{Reference}

ADORC (Acid deposition and oxidant research center) (2006) Tropospheric ozone a growing threat. ADORC, Niigata, p 26

Akimoto H (2003) Global air quality and pollution. Science 302:1716-1719

Baba M, Okazaki M (1998) Acidification in nitrogen-saturated forested catchment. Soil Sci Plant Nutr 44: 513-525

Baba M, Suzuki Y, Sasaki H, Matano K, Sugiura T, Kobayashi H (2001) Nitrogen retention in Japanese cedar stands in northern Honshu, with high nitrogen deposition. Water Air Soil Pollut 130: 1103-1108

Endo T, Yagoh H, Sato K, Matsuda K, Hayashi K, Noguchi I, Sawada K (2011) Regional characteristics of dry deposition of sulfur and nitrogen compounds at EANET sites in Japan from 2003 to 2008. Atmos Environ 45: 1259-1267

Environmental Laboratories Association (2003) The third report of the acid rain monitoring in Japan. Journal of Environmental Laboratories Association 28: 126-185 (In Japanese)

Fujii N, Tomaru N, Okuyama K, Koike T, Mikami T, Ueda K (2002) Chloroplast DNA phylogeography of Fagus crenata (Fagaceae) in Japan. Plant Syst Evol $232: 21-33$

Fujita S (2004) Study on the deposition of gaseous and particulate substances in East Asia. Journal of Japan Society for Atmospheric Environment 39: 107-118 (In Japanese with English summary)

Galloway JN, Townsend AR, Erisman JW, Bekunda M, Cai Z, Freney JR, Martinelli LA, Seitzinger SP, Sutton MA (2008) Transformation of the nitrogen cycle: Recent trends, questions, and potential solutions. Science 320: 889-892 
Hagiwara S (1977) Cline of leaf area in Fagus crenata. Plant Species Biol 1: 39-51 (In Japanese)

Häikiö E, Freiwald V, Silfver T, Beuker E, Holopainen T, Oksanen E (2007) Impacts of elevated ozone and nitrogen on growth and photosynthesis of European aspen (Populus tremula) and hybrid aspen (P. tremula $\times$ Populus tremuloides) clones. Can J For Res 37: 2326-2336

Han Z, Ueda H, Hozumi Y, Sakurai T (2007) Modeling study of long-range transport of $\mathrm{SO}_{2}, \mathrm{NO}_{\mathrm{X}}$ and $\mathrm{O}_{3}$ over Northeast Asia in March 2002. Water Air Soil Pollut 178: 195-205

Hanson PJ, Lindberg SE (1991) Dry deposition of reactive nitrogen compounds: a review of leaf, canopy and non-foliar measurements. Atmos Environ 25A: $1615-1634$

Holland EA, Braswell BH, Lamarque J-F, Townsend A, Sulzman J, Müller J-F, Dentener F, Brasseur G, Levy II H, Penner JE, Roelofs G-J (1997) Variations in the predicted spatial distribution of atmospheric nitrogen deposition and their impact on carbon uptake by terrestrial ecosystems. J Geophys Res 102: $15849-15866$

Holloway T, Levy II H, Carmichael G (2002) Transfer of reactive nitrogen in Asia: development and evaluation of a source-receptor model. Atmos Environ 36: $4251-4264$

International Energy Agency (2008) World Energy Outlook 2008. International Energy Agency, Paris. http://www.worldenergyoutlook.org/2008.asp Accessed 2 February 2011 
Ishii T, Matsumura H, Hayami H, Kohno Y (2007) Relationship between oxidant-based AOT40 and forest environmental conditions of damaged Japanese cedars in the Kanto plains. J Glob Environ Eng 12:51-62

Izuta T. (2003) Air pollution impacts on vegetation in Japan. In: Emberson L, Ashmore M, Murray F. (Eds) Air Pollution Impacts on Crops and Forests A Global Assessment, Imperial College Press, London, pp 89-101

Kärenlampi L, Skärby L (1996) Critical levels for ozone in Europe: testing and finalizing the concepts, UN-ECE workshop reports. Department of Ecology and Environmental Science, University of Kuopio, Finland, p 363

Karlsson PE, Uddling J, Braun S, Broadmeadow M, Elvira S, Gimeno BS, Le Thiec D, Oksanen E, Vandermeiren K, Wilkinson M, Emberson L (2004) New critical levels for ozone effects on young trees based on AOT40 and simulated cumulative leaf uptake of ozone. Atmos Environ 38: 2283-2294

Karnosky DF, Zak DR, Pregitzer KS, Awmack CS, Bockheim JG, Dickson RE, Hendrey GR, Host GE, King JS, Kopper BJ, Kruger EL, Kubiske ME, Lindroth RL, Mattson WJ, McDonald EP, Noormets A, Oksanen E, Parsons WFJ, Percy KE, Podila GK, Riemenschneider DE, Sharma P, Thakur R, Sôber A, Sôber J, Jones WS, Anttonen S, Vapaavuori E, Mankovska B, Heilman W, Isebrands JG. (2003) Tropospheric $\mathrm{O}_{3}$ moderates responses of temperate hardwood forests to elevated $\mathrm{CO}_{2}$ : a synthesis of molecular to ecosystem results from the Aspen FACE project. Funct Ecol 17: 289-304

Kimura SD, Saito M, Hara H, Xu YH, Okazaki M (2009) Comparison of nitrogen dry deposition on cedar and oak leaves in the Tama Hills using foliar rinsing method. Water Air Soil Pollut 202: 369-377 
Kohno Y, Matsumura H, Ishii T, Izuta T (2005) Establishing critical levels of air pollutants for protecting East Asian vegetation - A challenge. In: Omasa K, Nouchi I, De Kok LJ (eds) Plant responses to air pollution and global change. Springer-Verlag, Tokyo, pp 243-250

Koike $\mathrm{T}$ (1998) Comparative ecophysiology of the leaf photosynthetic traits in Japanese beech grown in provenances facing the Pacific Ocean and the Sea of Japan. Journal of phytogeography and taxonomy 46: 23-28 (In Japanese)

Kume A, Numata S, Watanabe K, Honoki H, Nakajima H, Ishida M (2009) Influence of air pollution on the mountain forests along the Tateyama-Kurobe Alpine route. Ecol Res 24: 821-830

Limm EB, Simonin KA, Bothman AG (2009) Foliar water uptake: a common water acquisition strategy for plants of the redwood forest. Oecologia, 161: $449-459$

Matsuda K, Fukuzaki N, Maeda M (2001) A case study on estimation of dry deposition of sulphur and nitrogen compounds by inferential method. Water Air Pollut 130: 553-558

Matyssek R, Sandermann H (2003) Impact of ozone on trees: an ecophysiological perspective. In: Esser K, Lüttge U, Beyschlag W, Hellwig F (eds) Progress in Botany 64. Springer-Verlage, Berlin Heidelberg: pp 349-404

Matyssek R, Bahnweg G, Ceulemans R, Fabian P, Grill D, Hanke DE, Kraigher H, Oßwald W, Rennenberg H, Sandermann H, Tausz M, Wieser G (2007) Synopsis of the CASIROZ case study: Carbon sink strength of Fagus sylvatica L. in a changing environment - Experimental risk assessment of mitigation by chronic ozone impact. Plant Biol 9: 163-180 
Mills G (2004) Mapping Manual 2004, Chapter III Mapping Critical Levels for Vegetation $\mathrm{p} 52$.

http://www.rivm.nl/en/themasites/icpmm/manual-and-downloads/index.html Accessed 2 February 2011

Ministry of the Environment (1996) About revision of the method for measuring the air pollutants such as sulfur dioxide in the atmosphere. Transmittal from Ministry Environment. http://www.env.go.jp/hourei/syousai.php?id=01000052 Accessed 2 February 2011 (In Japanese)

Ministry of the Environment (2004) Comprehensive report on acid deposition survey. Ministry of the Environment, Tokyo, p 432 (In Japanese)

Ministry of the Environment (2009) Report on long term acid deposition monitoring (fiscal 2003-2007). Ministry of the Environment, Tokyo, p191 (In Japanese)

Murai H, Yamatani K, Kataoka Y, Yui M (1991) Natural environment and its conservation on Buna (Fagus crenata) forest. Soft science, Inc., Tokyo, p 399 (In Japanese)

Nakashizuka T, Iida S (1995) Composition, dynamics and disturbance regime of temperate deciduous forests in Monsoon Asia. Vegetatio 121: 23-30

Nakashizuka T (2004) Story of forest trees and Japan. Tokai University Press, Hatano, p 252 (In Japanese)

Network Center for EANET (ed) (2007) Data report 2006. Network Center for EANET. http://www.eanet.cc/product.html Accessed 2 February 2011

Ohara T, Akimoto H, Kurokawa J, Horii N, Yamaji K, Yan X, Hatasaka T (2007) An Asian emission inventory of anthropogenic emission sources for the period 1980-2020. Atmos Chem Phys 7:4419-4444 
Ohara T (2011) Why is the increase of tropospheric ozone concentration in mountain and island regions in Japan? Japanese Journal of Ecology 60 (Accepted, In Japanese)

Okochi H, Igawa M (2001) Elevational patterns of acid deposition into a forest and nitrogen saturation on Mt. Oyama, Japan. Water Air Soil Pollut 130: $1091-1096$

Ollinger SV, Aber JD, Reich PB, Freuder RJ (2002) Interactive effects of nitrogen deposition, tropospheric ozone, elevated $\mathrm{CO}_{2}$ and land use history on the carbon dynamics of northern hardwood forests. Glob Chang Biol 8: 545-562

Paludan-Müller G, Saxe H, Leverenz JW (1999) Responses to ozone in 12 provenances of European beech (Fagus sylvatica): genotypic variation and chamber effects on photosynthesis and dry-matter partitioning. New Phytol $144: 261-273$

Pretzsch H, Dieler J, Matyssek R, Wipfler P (2009) Tree and stand growth of mature Norway spruce and European beech under long-term ozone fumigation. Environ Pollut 158: 1061-1070

Puxbaum H, Gregori M (1998) Seasonal and annual deposition rates of sulphur, nitrogen and chloride species to an oak forest in north-eastern Austria (Wolkersdorf, 240 m A.S.L). Atmos Environ 32: 3557-3568

Sase H, Takahashi A, Sato M, Kobayashi H, Nakata M, Totsuka T (2008) Seasonal variation in the atmospheric deposition of inorganic constituents and canopy interactions in a Japanese cedar forest. Environ Pollut 152: 1-10

Simpson D, Ashmore MR, Emberson L, Tuovinen J-P (2007) A comparison of two different approaches for mapping potential ozone damage to vegetation. A model study. Environ Pollut 146:715-725 
Takeda M, Aihara K (2007) Effects of ambient ozone concentrations on Beech (Fagus crenanta) seedlings in the Tanzawa Mountains, Kanagawa Prefecture, Japan. J Jpn Soc Atmos Environ 42: 107-117 (In Japanese with English summary)

Tanimoto H, Sawa Y, Matsueda H, Uno I, Ohara T, Yamaji K, Kurokawa J, Yonemura S. (2005) Significant latitudinal gradient in the surface ozone spring maximum over East Asia. Geophys Res Lett 32:L21805

Terazawa K, Koyama H (2008) Applied ecology for restoration of beech forests. Bun-ichi Sogo Shuppan Co., Tokyo, p 310 (In Japanese)

Thomas VFD, Braun S, Flückiger W (2005) Effects of simultaneous ozone exposure and nitrogen loads on carbohydrate concentrations, biomass, and growth of young spruce trees (Picea abies). Environ Pollut 137: 507-516

Utriainen J, Holopainen T (2001a) Influence of nitrogen and phosphorus availability and ozone stress on Norway spruce seedlings. Tree Physiol 21: 447-456

Utriainen J, Holopainen $\mathrm{T}$ (2001b) Nitrogen availability modifies the ozone responses of Scots pine seedlings exposed in an open-field system. Tree Physiol 21: 1205-1213

Wakamatsu S, Uno I, Ohara T (1998) Springtime photochemical air pollution in Osaka: Field observation. J Appl Meteorol 37: 1100-1106

Watanabe M, Yamaguchi M, Iwasaki M, Matsuo N, Naba J, Tabe C, Matsumura H, Kohno Y, Izuta T (2006) Effects of ozone and/or nitrogen load on the growth of Larix kaempferi, Pinus densiflora and Cryptomeria japonica seedlings. J Jpn Soc Atmos Environ 41:320-334. 
Watanabe M, Yamaguchi M, Tabe C, Iwasaki M, Yamashita R, Funada R, Fukami M, Matsumura H, Kohno Y, Izuta T (2007) Influences of nitrogen load on the growth and photosynthetic responses of Quercus serrata seedlings to $\mathrm{O}_{3}$. Trees 21:421-432

Watanabe M, Matsuo N, Yamaguchi M, Matsumura H, Kohno Y, Izuta T (2010) Risk assessment of ozone impact on the carbon absorption of Japanese representative conifers. Eur J Forest Res 129: 421-430

Yamaguchi M, Watanabe M, Iwasaki M, Tabe C, Matsumura H, Kohno Y, Izuta T (2007) Growth and photosynthetic responses of Fagus crenata seedlings to $\mathrm{O}_{3}$ under different nitrogen loads. Trees 21: 707-718

Yamaguchi M, Watanabe M, Matsumura H, Kohno Y, Izuta T (2010a) Effects of ozone on nitrogen metabolism in the leaves of Fagus crenata seedlings under different soil nitrogen loads. Trees 24: 175-184

Yamaguchi T, Noguchi I, Eguchi M. (2010b) Ambient ozone concentration around Lake Mashu, Hokkaido, Japan. Transactions of the meeting in Hokkaido branch of the Japanese forest society 58: 123-124 (In Japanese)

Yamaji K, Ohara T, Uno I, Tanimoto H, Kurokawa J, Akimoto H (2006) Analysis of the seasonal variation of ozone in the boundary layer in East Asia using the Community Multi-scale Air Quality model: What controls surface ozone levels over Japan? Atmos Environ 40: 1856-1868

Yamaji K, Ohara T, Uno I, Kurokawa J, Pochanart P, Akimoto H (2008) Future prediction of surface ozone over east Asia using Models-3 Community Multiscale Air Quality Modeling System and Regional Emission Inventory in Asia. J Geophys Res 113: D08306 
Yonekura T, Honda Y, Oksanen E, Yoshidome M, Watanabe M, Funada R, Koike T, Izuta T (2001) The influences of ozone and soil water stress, singly and in combination, on leaf gas exchange rates, leaf ultrastructural characteristics and annual ring width of Fagus crenata seedlings. J Jpn Soc Atmos Environ $36: 333-351$

Yoshikado H (2004) One possible factor causing recent trend of photochemical oxidants. J Jpn Soc Atmos Environ 39: 188-199 (In Japanese with English summary)

\section{Captions of figures}

Fig. 1 Monthly variations of estimated $K$ value (the ratio of concentration in the precipitation to that in the atmosphere) of $\mathrm{NO}_{\mathrm{X}}$ and $\mathrm{NH}_{\mathrm{Y}}$. Each value is the mean of the data in 1999, 2000 and 2001, and the standard deviation is shown by vertical bars

Fig. 2 The habitats of Fagus crenata and classification of the regions in Japan

Fig. 3 Relationships between AOT40 and relative whole-plant dry mass increment $\left(W D M_{\text {inc }}\right)$ (a) and between nitrogen supply and relative growth reduction per unit AOT40 (b) of Fagus crenata seedlings grown in the soil supplied nitrogen at 0 (N0),

20 (N20) and $50 \mathrm{~kg} \mathrm{ha}^{-1} \mathrm{year}^{-1}(\mathrm{~N} 50)$. The relative $W D M_{\text {inc }}$ and AOT40 were recalculated from the results of Yamaguchi et al. (2007). Regression line of (b): $y=$ $0.0055 x+0.230 ; R^{2}=0.967$ 
Fig. 4 The distribution of the estimated AOT40 of $\mathrm{O}_{3}$ and annual deposition of the total nitrogen $\left(T N_{\text {dep }}\right)$ in Japan. The AOT40 was accumulated during 0600-1800 hours from April to September and averaged across 1999 to 2001 . The $T N_{\text {dep }}$ was average across 1999 to 2001

Fig. 5 The distributions of $\mathrm{O}_{3}$-induced relative growth reduction $\left(R G_{\text {red }}\right)$ of Fagus crenata in Japan with consideration of nitrogen deposition (a) and without consideration of nitrogen deposition (b), which was estimated based on the $R G_{\text {red }}$ per unit AOT40 at $0 \mathrm{~kg} \mathrm{ha}^{-1}$ year $^{-1}$ of annual deposition of the total nitrogen

Fig. 6 The relationship between the AOT40 and $\mathrm{O}_{3}$-induced relative growth reduction $\left(R G_{\text {red }}\right)$ of Fagus crenata in Japan

Fig. 7 The relationship between the total nitrogen deposition $\left(T N_{\text {dep }}\right)$ and AOT40 in habitats of Fagus crenata in Japan 
Figure 1

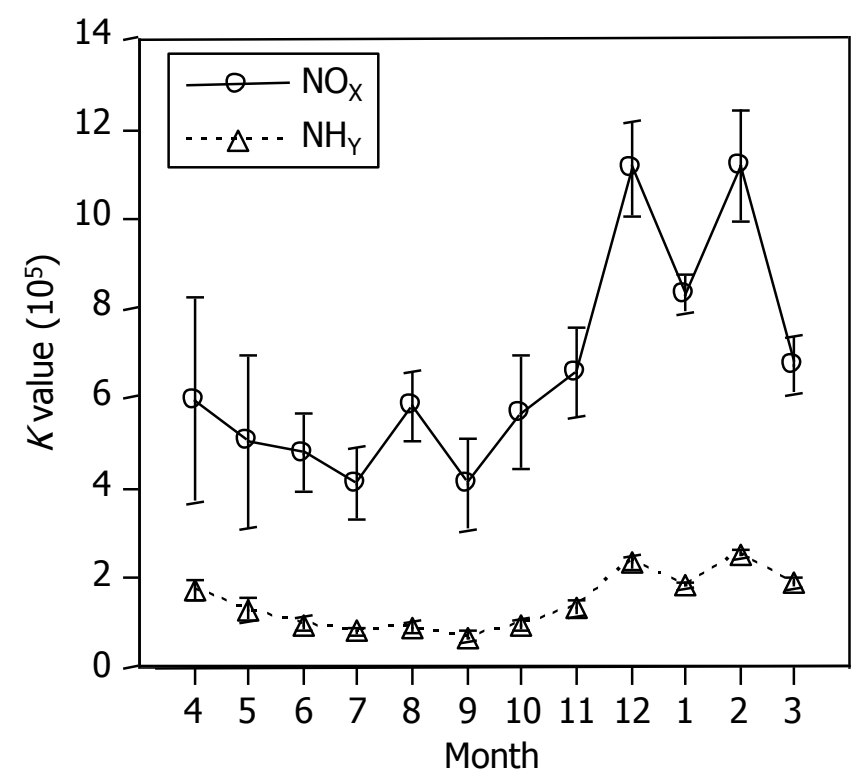


Figure 2

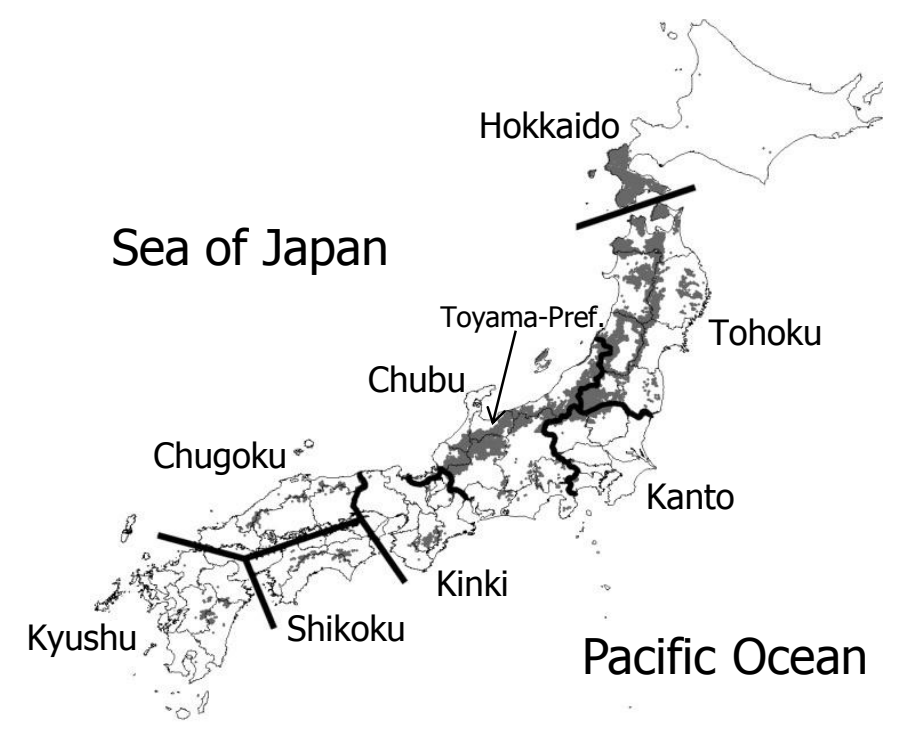


Figure 3
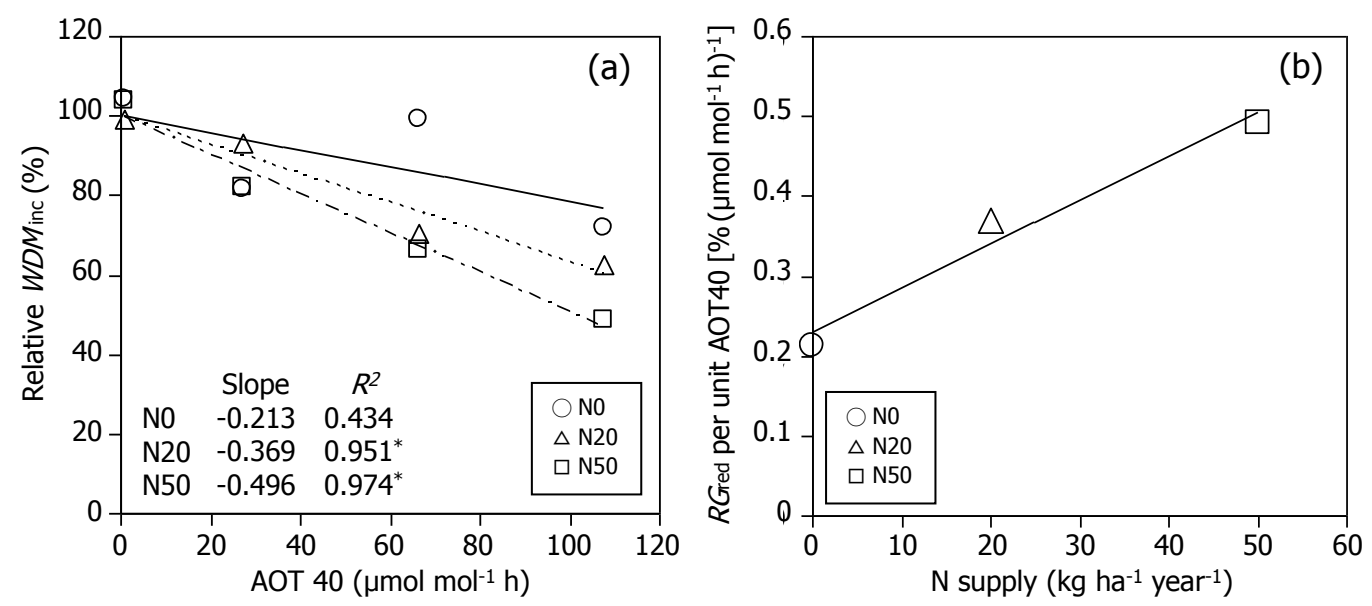
Figure 4

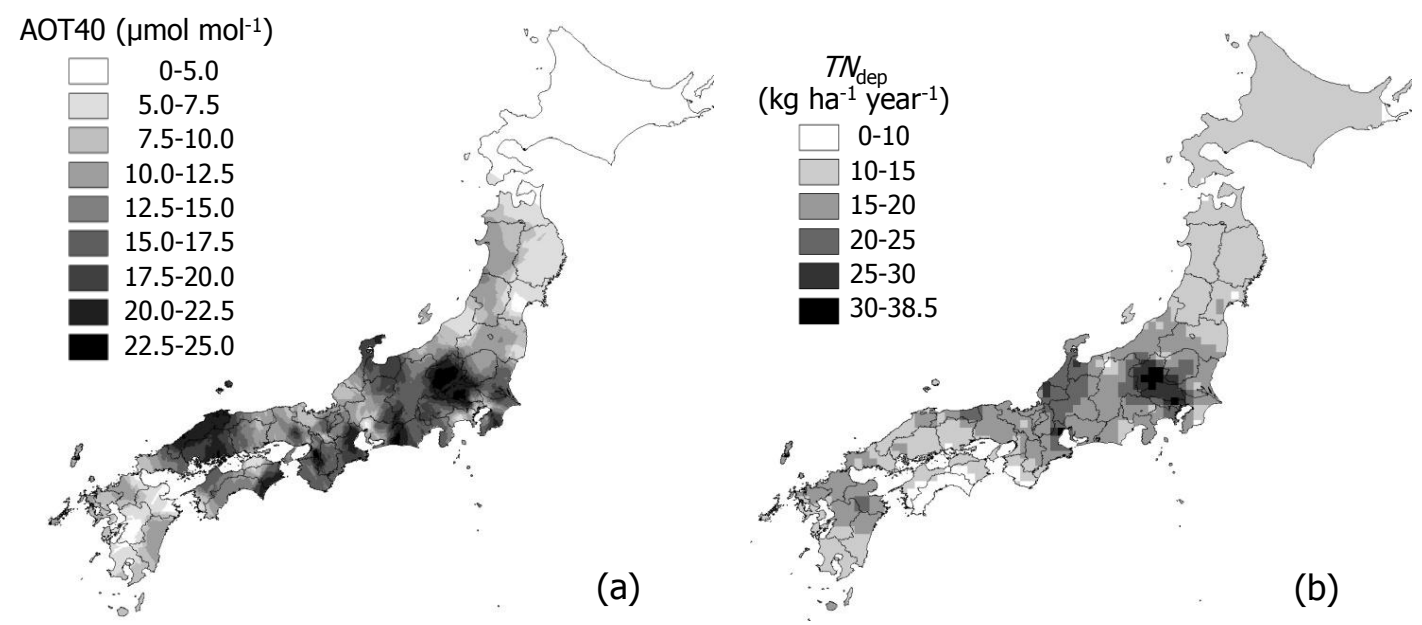


Figure 5

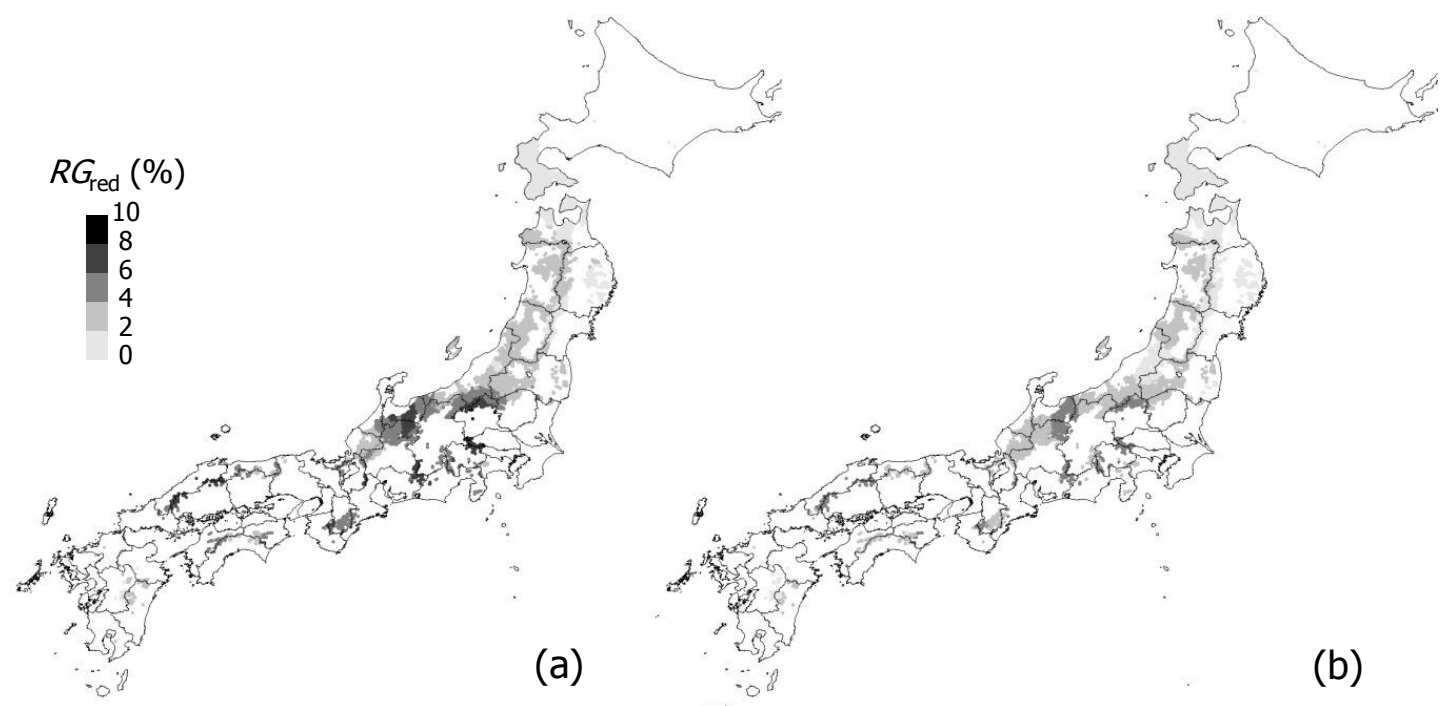


Figure 6

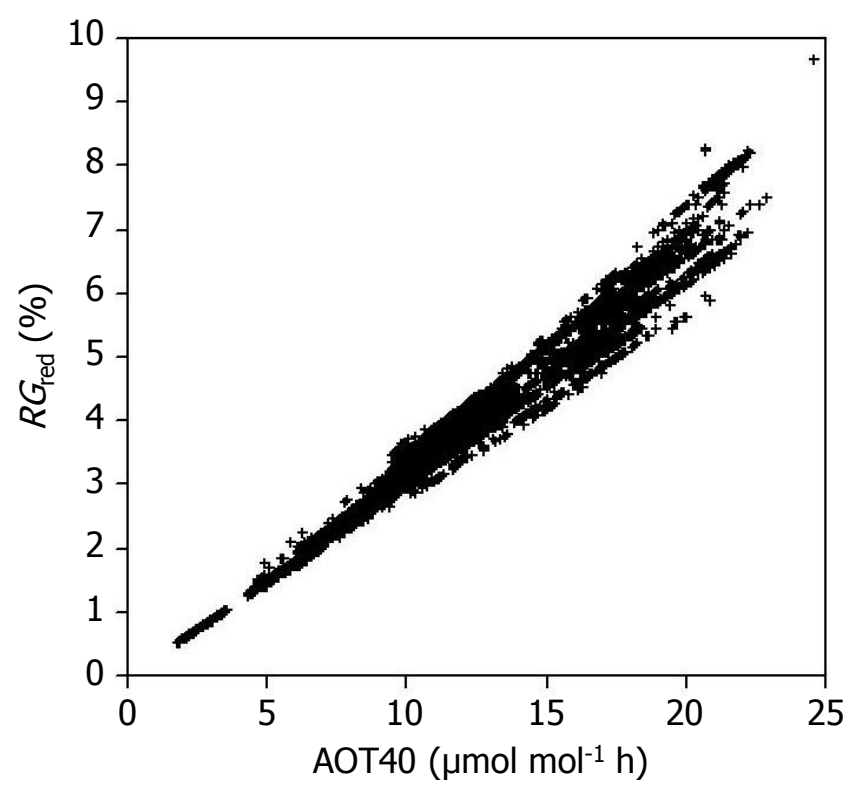


Figure 7

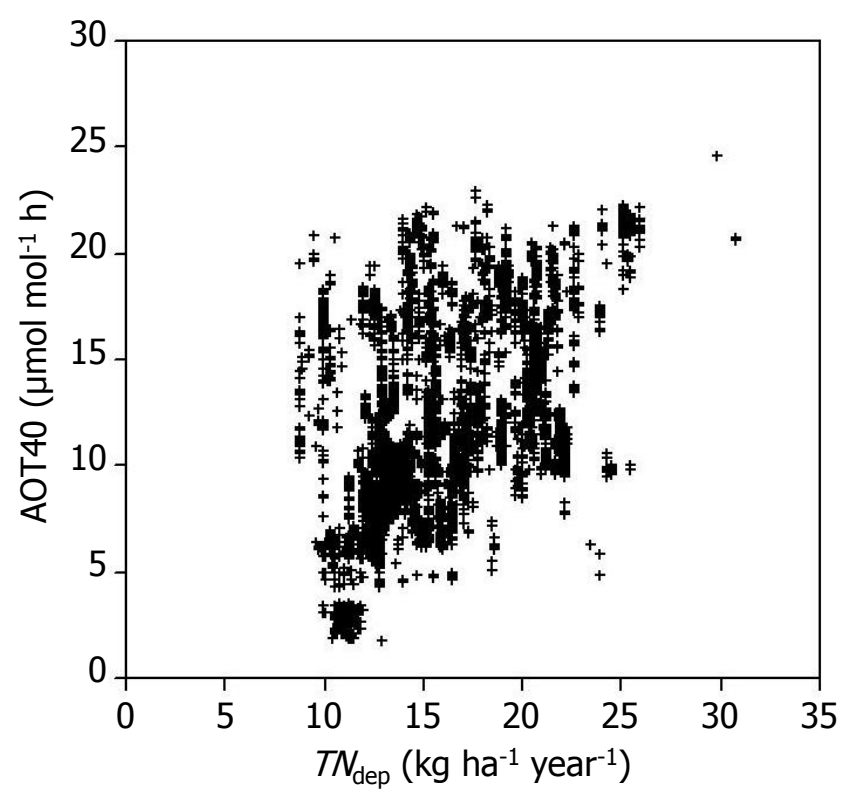

